Iberian Journal of the History of Economic Thought

ISSN: 2386-5768

\title{
William D. Grampp, historiador del pensamiento económico
}

\author{
Carlos Rodríguez Braun
}

William Dyer Grampp, el destacado historiador del pensamiento económico, murió en Chicago el pasado 30 de agosto, a los 105 años. Había nacido en Columbus, Ohio, el 22 de agosto de 1914.

Se graduó en la Universidad de Akron en 1936, doctorándose en 1944 en la de Chicago, con una tesis dirigida por Frank Knight, cuyo título anticipa lo que iban a ser sus investigaciones futuras: "Mercantilismo y Laissez Faire en la Discusión Política en Estados Unidos". Enseñó durante muchos años en la Universidad de Illinois en Chicago. Fue fundador, y luego presidente, de la History of Economics Society, y también integró el Consejo Editorial de History of Political Economy.

No hay mayor elogio de un académico que el constatar que llamaba la atención por la originalidad, profundidad y riqueza de sus ideas. Este fue el caso de Grampp, que en un artículo clásico, "Los elementos liberales en el mercantilismo inglés", despejó la asociación entre el mercantilismo y una batería de nociones, a menudo disparatadas, sistemáticamente contrarias al libre mercado. Concluyó que los mercantilistas

no creyeron en una economía dirigida total o básicamente por el Estado y los clásicos no creyeron en una economía enteramente controlada por un mercado competitivo. (Grampp 1971, 100)

El liberalismo fue el centro de sus estudios durante toda su vida, y lo analizó con destreza, no olvidando nunca las contradicciones y claroscuros que caracterizan su historia. En The Manchester School of Economics (Grampp 1960) recordó que ya en tiempos de Cobden y Bright se abrió paso la tesis (que está canónicamente presentada en los Principios de Mill) de que liberalismo equivale a libre comercio pero no necesariamente a la recomendación de una abstención sistemática de la interven- ción pública. Originada en el siglo XIX, esta idea llegaría a ser la ortodoxia del grueso de la izquierda y de la derecha, hasta nuestros días. Hablando de orígenes, Economic Liberalism (Grampp 1965) remonta los fundamentos históricos del liberalismo hasta los estoicos, lo que no llamaría la atención al Smith de $L a$ Teoría de los Sentimientos Morales.

Entre sus artículos sobre la historia del libre comercio destacan dos, publicados el mismo año, y que demuestran el poder de las doctrinas económicas. En uno de ellos revisa la declaración del Parlamento londinense de 1820, que estableció que el libre cambio habría de orientar la política comercial británica en el futuro. Y así sucedió, porque a mediados del siglo XIX las principales restricciones comerciales habían desaparecido. Fue una decisión política adoptada por los gobernantes, los tories, con apoyo de los whigs:

No quiero decir que los políticos ignoraron las consideraciones económicas, que les influyeron, y mucho. Pensaron en la riqueza de la nación, o, como diríamos ahora, en la renta per cápita. Creyeron que el libre comercio la incrementaría. Lo dijeron, y actuaron en consecuencia. Los economistas clásicos lo habían venido proclamando durante más de cincuenta años, y lo cierto fue que les hicieron caso. (Grampp 1987a, 100)

En la misma línea, el otro artículo desafía una interpretación muy extendida, según la cual el libre comercio se impuso en el siglo XIX en Gran Bretaña porque fue promovido por empresarios que esperaban beneficiarse de él. Sostiene Grampp que no fue así, y que las argumentaciones de los pensadores liberales se abrieron camino porque calaron en la opinión pública y fueron puestas en práctica por políticos que realmente pensaron que beneficiarían al grueso de la población (1987b). 
Como explican Carpenter y Moss, la visión de Grampp sobre las políticas liberalizadoras es diferente de la de Stigler o la Public Choice, porque subraya que dichas políticas no obedecieron a intereses sino a razones librecambistas que se combinaron con un extenso y conocido catálogo de excepciones al laissez faire (Carpenter y Moss 2001). El marco en el que ello se produjo venía condicionado por dos objetivos de la política clásica: la riqueza y el poder, lo que dio lugar a ambivalencias entre los economistas desde Adam Smith, cuyo liberalismo ha sido ampliamente debatido, de hecho, desde la época del propio pensador escocés hasta hoy (Rodríguez Braun 2019). En cuanto a los promotores del libre comercio, como la llamada Escuela de Manchester, apelaron sin duda a Smith, pero no fueron teóricos sino lobbies con buena capacidad de comunicación -ellos fundaron en 1843 The Economist, que tenía en su misma mancheta la consigna del free trade.

Grampp investigó también la historia de los enemigos del liberalismo, y lo hizo desde diversos ángulos, algunos llamativos. Por ejemplo, observó que los economistas clásicos fueron tachados en Inglaterra de escoceses, judíos y subversivos. Todo eso era verdad en parte, reconoció Grampp: la economía clásica empezó efectivamente en Escocia, Ricardo era judío, el liberalismo fue defendido por los $R a$ dicals en el Parlamento, y ciertamente pretendía amenazar algunas instituciones relevantes del Reino Unido (Grampp 1976).

En los matices con los que pondera el liberalismo se nota la influencia de sus profesores, en especial Knight y Viner, pero Grampp fue un liberal, y desde muy temprano. Ya en la treintena reprochó a los socialdemócratas porque no consiguen sus benéficos objetivos teóricos, y en la práctica quebrantan la libertad y las instituciones sociales sobre las que descansa, como la familia (Grampp 1949).

$Y$ fue liberal hasta una edad provecta. En 1980 se retiró formalmente de la docencia, pero de la investigación no, e incluso se lanzó a un campo nuevo, donde también llamó la atención, concitando no pocas fobias. A finales de esa década publicó Pricing the priceless, donde estudió la economía del mundo de la cultura, del arte y de los artistas, supuestamente apartados de la fría lógica de la ciencia lúgubre, probando que no lo están en absoluto (Grampp 1989). Su defensa allí del liberalismo, y su condena a la intervención del Estado en unos ámbitos en donde casi nadie la discute, hacen que Carpenter y Moss lo cataloguen como un integrante más de la Escuela de Chicago.

En unas líneas que escribió para SHOE el pasado 3 de septiembre, Joseph Persky afirmó que Grampp disfrutaba debatiendo: "Lo que más le gustaba era la discusión intelectual y las historias económicas. Estaba encantado de polemizar con personas de izquierdas e incluso con sus correligionarios en otras latitudes del espectro político". Soy testigo de que era así, porque tuve el placer de conocer a Bill Grampp. Me honró invitándome a un seminario del Liberty Fund en Niza a comienzos de los años noventa. Allí conocí también a Alan Peacock, con quien mantuve asimismo contacto después, a raíz de mi traducción de su libro Elección Pública para Alianza Editorial, que generosamente prologó-más tarde escribió una amable nota para An Eponymous Dictionary of Economics, que coeditamos con Julio Segura. Tanto Peacock como Grampp eran liberales, pero yo recuerdo a Bill persiguiendo a Alan en los descansos del seminario para presentarle un nuevo argumento en contra de la intervención del Estado en la lotería, aunque recaudase fondos que se destinaran a una finalidad plausible, como el respaldo financiero a las artes.

Bill Grampp tuvo la amabilidad de invitarme a leer y comentar el borrador de un artículo que estaba preparando sobre Adam Smith y la mano invisible. Nuevamente, era una pieza sobre el liberalismo que se apartaba de lo convencional, porque Grampp critica las interpretaciones más extendidas sobre esta célebre metáfora. Defiende la tesis de que la mano invisible desfigura la teoría smithiana, confundiendo su defensa del comercio libre, y en realidad tiene que ver más con la inducción a la inversión del capital en cada nación. Fue publicado en el 2000, cuando Bill tenía 86 años.

Descanse en paz, William D. Grampp, espejo de historiadores del pensamiento económico. 


\section{Referencias}

Carpenter, Kenneth E. y Moss, Laurence S. 2001. The craft of William D. Grampp: historian of economics, en Steven G. Medema y Warren J. Samuels, ed., Historians of Economics and Economic Thought. The Construction of Disciplinary Memory, Londres y Nueva York, Routledge, 93-116.

Grampp, William D. 1949. Reseña de Planning and the Price System: The Liberal Socialist Solution, de James Meade, Southern Economic Journal, 16 (2) 225-227.

-1960. The Manchester School of Economics, Stanford y Londres, Stanford University Press y Oxford University Press.

-1965. Economic Liberalism, 2 vols., Nueva York, Random House.

-1971. Los elementos liberales en el mercantilismo inglés, en Joseph J. Spengler y William R. Allen, eds., El pensamiento económico de Aristóteles a Marshall, Madrid, Tecnos, 75-105.

-1976. Scots, Jews, and Subversives Among the Dismal Scientists, Journal of Economic History, 36

(3) $543-571$.

-1987a. How Britain Turned to Free Trade, Business History Review, 61 (1) 86-112.

-1987b. Britain and Free Trade: In Whose Interest?, Public Choice, 55 (3) 245-256.

-1989. Pricing the priceless. Art, Artists, and Economics, Nueva York, Basic Books [trad. esp. Ariel].

-2000. What did Smith Mean by the Invisible Hand?, Journal of Political Economy, 108 (3) 441-465.

Rodríguez Braun, Carlos 2019. Adam Smith's Liberalism, The Review of Austrian Economics, forthcoming. 